\title{
Immunotherapeutic approach to a case of advanced hepatoid adenocarcinoma of the lung
}

\author{
Anthony El Khoury $(\mathbb{D} \cdot$ Marc El Khoury · Russel De Luca
}

Received: 4 March 2019 / Accepted: 21 May 2019 / Published online: 12 June 2019

(C) The Author(s) 2019

\begin{abstract}
Summary
Rationale Hepatoid adenocarcinoma (HAC) is an extrahepatic primary tumor that expresses morphological features resembling hepatocellular carcinoma. This rare malignant tumor has been described in the gastrointestinal (GI) tract, the testes, the ovaries, and rarely, the lungs. Despite there being no standardized management protocol for this case with poor prognosis, the literature describes responses to treatment with cisplatin-etoposide chemotherapy.

Objective We present an updated review of all cases of HAC of the lung and the favorable results of a novel management method for this type of tumor.

Results A table including all the HAC of the lung cases on the electronic database PubMed since 1980 is compiled. Here we present a case of primary HAC of the lungs, initially managed with cisplatin-etoposide without favorable response to treatment. The immunohistochemical profile of the tumor allowed for the novel use of immunotherapy in the setting of primary lung HAC, with favorable response.

Conclusion and outlook The case presented here is of interest as it adopts a novel immunotherapeutic approach to HAC, yielding a promising outcome. This highlights the importance of molecular typing and immunohistochemical profiling in the diagnosis and management of non-small cell lung cancer.
\end{abstract}

\section{A. El Khoury $(\bowtie)$ \\ St Georges', University of London, Cranmer \\ Terrace, London, United Kingdom \\ m1603026@sgul.ac.uk}

\section{El Khoury}

St Edmund's College, Cambridge University, Mount

Pleasant, Cambridge, Cambridgeshire, United Kingdom

\section{R. De Luca}

Tate Cancer Center, University of Maryland Medical

Systems, 205 HospitalDrive, Glen Burnie, MD 21061, USA
Keywords Neoplasm · Non-small cell lung cancer . Novel therapy $\cdot$ Pembrolizumab · Adenocarcinoma
Abbreviations
AFP Alpha fetoprotein
CDX Caudal type homeobox
CEA Carcinoembryonic antigen
CK Cytokeratin
HAC Hepatoid adenocarcinoma
HCC Hepatocellular carcinoma
PAX Paired box gene
PSA Prostate-specific antigen
TTF Thyroid transcription factor

\section{Introduction}

Hepatoid adenocarcinomas (HAC), first described in 1985 by Ishikura et al. [1], are a rare type of extrahepatic alpha-fetoprotein secreting tumor with hepatocellular carcinoma (HCC) like morphology. Since that time, only 33 cases of HAC of the lung have been published in PubMed, and the main features of all these cases are summarized in Table 1.

Two criteria are usually described for the diagnosis of hepatoid adenocarcinoma, the first being a mixture of tubular or papillary adenocarcinoma with sheetlike or trabecular proliferation of neoplastic cells within an AFP-producing carcinoma. The second criterion is cells with abundant, eosinophilic cytoplasm and centrally located nuclei, in the sheet-like or trabeculated portion [2]. The immunohistochemical profile of HAC tumors has shown to be variable. It has been found that $91.6 \%$ of HAC tumors stain positive for AFP [3, 4].

Primary HAC of the lung comprises $5 \%$ of all reported cases of hepatoid adenocarcinoma, with the stomach being the most common site of occurrence [5]. The literature shows that $100 \%$ of HAC stain pos- 
Table 1 Summary of previously reported cases of hepatoid adenocarcinoma of the lung. Table compiled from adaptation of Grossman, Beasley and Braman (2016) and a PubMed

\begin{tabular}{|c|c|c|c|c|c|c|c|c|c|c|}
\hline Autor & $\begin{array}{l}\text { Publication } \\
\text { year }\end{array}$ & $\begin{array}{l}\text { Age } \\
\text { (years) }\end{array}$ & Gender & Location & Size (cm) & Smoker & $\begin{array}{l}\text { AFP level } \\
\text { (ng/uil) }\end{array}$ & Stage & Progression & Treatment \\
\hline Yasunami et al. [7] & 1981 & 67 & Male & Left Upper Lobe & "Fist-sized" & $\begin{array}{l}\text { Not } \\
\text { given }\end{array}$ & 19,000 & pT3 N2 & $\begin{array}{l}\text { Rib and } \\
\text { vertebra } \\
\text { metastases }\end{array}$ & $\begin{array}{l}\text { XRT, } \\
\text { Immuno tx } \\
\text { (BCG) }\end{array}$ \\
\hline Yokoyama et al. [8] & 1981 & 69 & Male & $\begin{array}{l}\text { Right Lower } \\
\text { Lobe }\end{array}$ & $11 \times 11 \times 7$ & $\begin{array}{l}\text { Not } \\
\text { given }\end{array}$ & 5050 & pT3 M1b & $\begin{array}{l}\text { Not applica- } \\
\text { ble }\end{array}$ & $\mathrm{N} / \mathrm{A}$ \\
\hline Miyake et al. [9] & 1986 & 40 & Male & $\begin{array}{l}\text { Right Upper } \\
\text { Lobe }\end{array}$ & $8 \times 9 \times 7$ & $\begin{array}{l}\text { Not } \\
\text { given }\end{array}$ & 3090 & pT3M1b & $\begin{array}{l}\text { Not applica- } \\
\text { ble }\end{array}$ & Surg \\
\hline Miyake et al. [9] & 1986 & 55 & Male & $\begin{array}{l}\text { Right Upper } \\
\text { Lobe }\end{array}$ & 5 & $\begin{array}{l}\text { Not } \\
\text { given }\end{array}$ & 2123 & pT2a M1b & $\begin{array}{l}\text { Not applica- } \\
\text { ble }\end{array}$ & Surg \\
\hline Miyake et al. [10] & 1987 & 73 & Male & Left Upper Lobe & $5 \times 6 \times 5$ & $\begin{array}{l}\text { Not } \\
\text { given }\end{array}$ & 1039 & pT2b N2 & $\begin{array}{l}\text { Mediastinal, } \\
\text { LN, brain } \\
\text { metastases }\end{array}$ & Surg, XRT \\
\hline Okunaka et al. [11] & 1992 & 49 & Male & $\begin{array}{l}\text { Right Upper } \\
\text { Lobe }\end{array}$ & $6 \times 5 \times 5$ & $\begin{array}{l}\text { Not } \\
\text { given }\end{array}$ & 9300 & eT3 & $\begin{array}{l}\text { No pro- } \\
\text { gression at } \\
11 \text { months }\end{array}$ & Surg \\
\hline Arnould et al. [2] & 1997 & 36 & Male & Left Upper Lobe & 10 & Yes & 11,600 & pT4 N2 & $\begin{array}{l}\text { Brain } \\
\text { Metasta- } \\
\text { sis }\end{array}$ & $\begin{array}{l}\text { Chemo, } \\
\text { Surg }\end{array}$ \\
\hline Nasu et al. [12] & 1997 & 63 & Male & $\begin{array}{l}\text { Right Upper } \\
\text { Lobe }\end{array}$ & $14 \times 13 \times 12$ & $\begin{array}{l}\text { Not } \\
\text { given }\end{array}$ & 14,000 & cT4 N2 & $\begin{array}{l}\text { Lung, right } \\
\text { adrenal, } \\
\text { brain metas- } \\
\text { tases }\end{array}$ & Chemo \\
\hline $\begin{array}{l}\text { Carlinfante et al. } \\
\text { [13] }\end{array}$ & 2000 & 82 & Male & Left Lower Lobe & 3.5 & Yes & $\begin{array}{l}\text { Not } \\
\text { Assayed }\end{array}$ & cT2a NO MO & $\begin{array}{l}\text { No pro- } \\
\text { gression } \\
7 \text { years af- } \\
\text { ter surgery }\end{array}$ & Surg \\
\hline Genova [14] & 2002 & 71 & Male & Left Upper Lobe & $7.7 \times 6.4$ & $\begin{array}{l}\text { Not } \\
\text { given }\end{array}$ & $\begin{array}{l}\text { Not } \\
\text { Assayed }\end{array}$ & pT3 N0 & $\begin{array}{l}\text { No pro- } \\
\text { gression at } \\
24 \text { months }\end{array}$ & Surg \\
\hline Hayashi et al. [15] & 2002 & 55 & Male & $\begin{array}{l}\text { Right Upper } \\
\text { Lobe }\end{array}$ & $5 \times 4.8 \times 6.5$ & Yes & 89 & pT2b N0 & $\begin{array}{l}\text { No pro- } \\
\text { gression at } \\
32 \text { months }\end{array}$ & Surg \\
\hline Hiroshima et al. [16] & 2002 & 71 & Male & $\begin{array}{l}\text { Right Lower } \\
\text { Lobe }\end{array}$ & $10.5 \times 8.5 \times 7$ & Yes & 7417 & pT3 N1 & $\begin{array}{l}\text { Lung and } \\
\text { brain metas- } \\
\text { tases }\end{array}$ & Surg \\
\hline lino et al. [17] & 2003 & 63 & Male & $\begin{array}{l}\text { Right Upper } \\
\text { Lobe }\end{array}$ & $2.8 \times 2.5$ & $\begin{array}{l}\text { Not } \\
\text { given }\end{array}$ & N/A & cT1 N0 M0 & $\begin{array}{l}\text { No pro- } \\
\text { gression } \\
5 \text { months } \\
\text { after } \\
\text { surgery }\end{array}$ & Surg \\
\hline Oshiro et al. [18] & 2004 & 77 & Male & $\begin{array}{l}\text { Right Lower } \\
\text { Lobe }\end{array}$ & Not Reported & $\begin{array}{l}\text { Not } \\
\text { given }\end{array}$ & $\begin{array}{l}\text { Not } \\
\text { Assayed }\end{array}$ & cT2 NO MO & $\begin{array}{l}\text { Liver metas- } \\
\text { tasis }\end{array}$ & Surg \\
\hline Ivan et al. [19] & 2007 & 54 & Male & Left Upper Lobe & $13 \times 11$ & Yes & 14,540 & pT4 N3 M1 & $\mathrm{N} / \mathrm{A}$ & $\begin{array}{l}\text { Chemo, } \\
\text { XRT }\end{array}$ \\
\hline Kishimoto et al. [20] & 2008 & 64 & Male & Left Lower Lobe & $7.5 \times 7 \times 4$ & $\begin{array}{l}\text { Not } \\
\text { given }\end{array}$ & 673 & cT3 NO MO & $\begin{array}{l}\text { Not re- } \\
\text { ported }\end{array}$ & Surg \\
\hline Kim et al. [21] & 2009 & 49 & Male & Left Upper Lobe & 6 & $\begin{array}{l}\text { Not } \\
\text { given }\end{array}$ & 14,707 & pT2b N1 & $\begin{array}{l}\text { Not re- } \\
\text { ported }\end{array}$ & Surg \\
\hline Valentino et al. [22] & 2012 & 71 & Male & $\begin{array}{l}\text { Right Lower } \\
\text { Lobe }\end{array}$ & $1.8 \times 1.5 \times 1.5$ & No & 34,791 & pT1 N0 M1 & $\begin{array}{l}\text { Died } \\
4 \text { months } \\
\text { after pre- } \\
\text { sentation }\end{array}$ & $\begin{array}{l}\text { Chemo, } \\
\text { XRT, Surg }\end{array}$ \\
\hline Lin et al. [23] & 2013 & 66 & Male & $\begin{array}{l}\text { Right Upper } \\
\text { Lobe }\end{array}$ & $7.4 \times 6 \times 4.8$ & Yes & 8686 & cT3 N2 M0 & $\begin{array}{l}\text { Alive } \\
57 \text { months } \\
\text { after pre- } \\
\text { senting }\end{array}$ & $\begin{array}{l}\text { Surgery, } \\
\text { adjuvant } \\
\text { chemo }\end{array}$ \\
\hline Haninger et al. [24] & 2014 & 51 & Male & $\begin{array}{l}\text { Right Upper } \\
\text { Lobe }\end{array}$ & $4.2 \times 3.7$ & Yes & $\begin{array}{l}1.3 \\
\text { (post-tx) }\end{array}$ & $\begin{array}{l}\text { cT2a N3 } \\
\text { M1b }\end{array}$ & $\begin{array}{l}\text { Died } \\
14 \text { months } \\
\text { after pre- } \\
\text { sentation }\end{array}$ & $\begin{array}{l}\text { Chemo, } \\
\text { XRT, Surg }\end{array}$ \\
\hline
\end{tabular}

search (keywords: Hepatoid adenocarcinoma AND Lung between June 2015 and present) 


\section{case report}

Table 1 (Continued)

\begin{tabular}{|c|c|c|c|c|c|c|c|c|c|c|}
\hline Autor & $\begin{array}{l}\text { Publication } \\
\text { year }\end{array}$ & $\begin{array}{l}\text { Age } \\
\text { (years) }\end{array}$ & Gender & Location & Size $(\mathrm{cm})$ & Smoker & $\begin{array}{l}\text { AFP level } \\
\text { (ng/uil) }\end{array}$ & Stage & Progression & Treatment \\
\hline Haninger et al. [24] & 2014 & 52 & Male & $\begin{array}{l}\text { Right Upper } \\
\text { Lobe }\end{array}$ & 2.5 & Yes & $\begin{array}{l}\text { Not } \\
\text { Assayed }\end{array}$ & $\begin{array}{l}\text { cT1b N0 } \\
\text { M1b }\end{array}$ & $\begin{array}{l}\text { Alive } \\
37 \text { months } \\
\text { after pre- } \\
\text { sented }\end{array}$ & $\begin{array}{l}\text { Surg, } \\
\text { Chemo, } \\
\text { XRT }\end{array}$ \\
\hline Haninger et al. [24] & 2014 & 64 & Male & Left Upper Lobe & $3.2 \times 2.2$ & Yes & 1 (post-tx) & $\begin{array}{l}\text { cT2a N0 } \\
\text { M1b }\end{array}$ & $\begin{array}{l}\text { Died } \\
10 \text { months } \\
\text { after pre- } \\
\text { sentation }\end{array}$ & $\begin{array}{l}\text { Surg, } \\
\text { Chemo, } \\
\text { XRT }\end{array}$ \\
\hline Haninger et al. [24] & 2014 & 54 & Female & Left Upper Lobe & 1 & Yes & $\begin{array}{l}\text { Not } \\
\text { Assayed }\end{array}$ & $\begin{array}{l}\text { cT1a N0 } \\
\text { M1b }\end{array}$ & $\begin{array}{l}\text { Alive } \\
9 \text { years } \\
\text { after pre- } \\
\text { sentation }\end{array}$ & $\begin{array}{l}\text { Chemo, } \\
\text { XRT, Surg }\end{array}$ \\
\hline Haninger et al. [24] & 2014 & 60 & Male & $\begin{array}{l}\text { Right Upper } \\
\text { Lobe }\end{array}$ & $11.2 \times 10.1 \times 8.5$ & Yes & 4410 & cT3 N2 M1b & $\begin{array}{l}\text { Alive } \\
1 \text { month } \\
\text { after pre- } \\
\text { sentation }\end{array}$ & $\begin{array}{l}\text { Chemo, } \\
\text { XRT }\end{array}$ \\
\hline Shaib et al. [25] & 2014 & 52 & Male & Left Upper Lobe & $11.8 \times 12 \times 8$ & Yes & 5000 & cT3 N0 M1 & $\begin{array}{l}\text { Alive } \\
6-7 \text { months } \\
\text { after pre- } \\
\text { senting }\end{array}$ & $\begin{array}{l}\text { Palliative } \\
\text { Chemo }\end{array}$ \\
\hline Che et al. [26] & 2014 & 48 & Male & Left Upper Lobe & $7.8 \times 7.9 \times 10$ & Yes & 6283 & pT4 N1 M0 & $\begin{array}{l}\text { Died } \\
36 \text { months } \\
\text { after pre- } \\
\text { sentation }\end{array}$ & $\begin{array}{l}\text { Chemo, } \\
\text { XRT }\end{array}$ \\
\hline $\begin{array}{l}\text { Gavrancic and Park } \\
\text { [27] }\end{array}$ & 2015 & 64 & Male & $\begin{array}{l}\text { Right Upper } \\
\text { Lobe }\end{array}$ & $3.8 \times 2.9$ & $\begin{array}{l}\text { Not } \\
\text { given }\end{array}$ & 181 & cT2 N2 M1 & $\begin{array}{l}\text { Died } \\
11 \text { months } \\
\text { after pre- } \\
\text { sentation }\end{array}$ & $\begin{array}{l}\text { Chemo, } \\
\text { Sorafenib, } \\
\text { XRT }\end{array}$ \\
\hline Grossman et al. [5] & 2016 & 54 & Male & $\begin{array}{l}\text { Right Up- } \\
\text { per Lobe/ } \\
\text { Paratracheal }\end{array}$ & $4.1 \times 5.1$ & Yes & 2 & pT4 N0 M1b & $\begin{array}{l}\text { Died } \\
4 \text { months } \\
\text { after pre- } \\
\text { sentation }\end{array}$ & XRT \\
\hline Qian et al. [28] & 2016 & 79 & Male & Right Parahilar & $2.7 \times 2.6$ & Yes & 698 & Not reported & $\begin{array}{l}\text { Died } \\
25 \text { days } \\
\text { after tx start } \\
\text { by lung } \\
\text { infection }\end{array}$ & Chemo \\
\hline Motooka et al. [29] & 2016 & 69 & Male & Left Upper Lobe & 4.3 & Yes & 4497 & pT2a NO MO & $\begin{array}{l}\text { Alive } \\
51 \text { months } \\
\text { after } \\
\text { surgery }\end{array}$ & $\begin{array}{l}\text { Surg, } \\
\text { Adjuvant } \\
\text { chemo }\end{array}$ \\
\hline Sun et al. [30] & 2016 & 59 & Male & $\begin{array}{l}\text { Right Upper } \\
\text { Lobe }\end{array}$ & $4.5 \times 3.8 \times 3.5$ & Yes & $\begin{array}{l}\text { Not } \\
\text { assayed }\end{array}$ & pT2a N0 M0 & $\begin{array}{l}\text { Alive with } \\
\text { no recur- } \\
\text { rence or } \\
\text { metastasis } \\
23 \text { months } \\
\text { after } \\
\text { surgery }\end{array}$ & Surg \\
\hline Valle et al. [31] & 2017 & 61 & Male & Left sided & Not reported & $\begin{array}{l}\text { Not } \\
\text { given }\end{array}$ & $\begin{array}{l}\text { Not } \\
\text { assayed }\end{array}$ & Stage IV A & $\begin{array}{l}\text { Further } \\
\text { metastasis } \\
\text { to tonsil }\end{array}$ & Chemo \\
\hline Basse et al. [32] & 2018 & 43 & $\begin{array}{l}\text { Not } \\
\text { given }\end{array}$ & Right Hilar & Not reported & Yes & $\begin{array}{l}\text { Not } \\
\text { assayed }\end{array}$ & Metastatic & $\begin{array}{l}\text { Died af- } \\
\text { ter partial } \\
\text { immunotx } \\
\text { response } \\
\text { due to in- } \\
\text { fectious } \\
\text { complica- } \\
\text { tions }\end{array}$ & $\begin{array}{l}\text { Chemo, } \\
\text { Immuno }\end{array}$ \\
\hline
\end{tabular}

Tx treatment, XRT Radiotherapy, Chemo Chemotherapy, Surg Surgery, AFP Alphafetoprotein 
itive for AFP, CEA, CK18 and CK19 [3]. Furthermore, a report by Shao et al. [6] extensively discusses the various management approaches used in previous cases of HAC of the lung, and concludes that an optimal regiment for the systematic treatment of advanced HAC of the lung remains elusive.

\section{Case history}

A 59-year-old African-American male presented to the emergency department with right sided chest pain of recent onset, and numbness in the right upper extremity (RUE). The patient is a former smoker with $>30$ pack-year history and is currently employed as a transportation supervisor. The patient's family history is significant for colon cancer in the father. A chest CT showed a $9.3 \times 7.2 \times 6.8 \mathrm{~cm}$ mass located in the upper lobe of the right lung. The mass presented with hilar lymphadenopathy. The CT scan did not exhibit contralateral adenopathy, and the CT-guided lung biopsy was inconclusive. The patient was scheduled for a repeat biopsy and a brain MRI to rule out brain metastases.

Patient underwent navigational bronchoscopy with core needle biopsy. The pathological findings were as follows: poorly differentiated carcinoma with hepatoid features. Brain MRI ruled out brain metastases. The surgical pathology report (processed at the University of Maryland Baltimore Washington Medical Center Laboratories) reads as follows:

- Fragments of lung tissue showing a poorly differentiated carcinoma consistent with hepatoid carcinoma

- Tumor cells are positive for CK7 immunohistochemical stain and negative for TTF1, CK5/6

- The PSA, CK20, CDX2, PAX8, GATA3 and PSA immunohistochemical stains are non-contributory

- Cytology specimen from 4R Lymph Node aspirate is positive for HEPAR immunohistochemical stain consistent with hepatoid carcinoma

PET-CT ruled out a primary hepatocellular carcinoma and showed a $4.6 \times 4.4 \mathrm{~cm}$ left adrenal mass. At that time, the patient's symptomatology was significant for decreased appetite, weight loss of $2 \mathrm{~kg}$, and RUE numbness. Complete blood count was normal. AFP level was $1.5 \mathrm{ng} / \mathrm{ml}$ (reference range $<10 \mathrm{ng} / \mathrm{ml}$ ). CEA level was $32 \mathrm{ng} / \mathrm{ml}$ (reference range $<3 \mathrm{ng} / \mathrm{ml}$ ). The patient was started on a combination of cisplatin and etoposide chemotherapy.

Tumor was confirmed as primary hepatoid adenocarcinoma of the lung, stage IV-A. TNM staging: $\mathrm{cT}_{4} \mathrm{~N}_{2} \mathrm{M}_{1 \mathrm{~b}}$ : metastases were found in the mediastinal and hilar lymph nodes and the left adrenal gland. The immunohistochemical profile of the tumor was obtained: histological grade 3. EGFR negative. ALKrearrangement: negative. BRAF w/t. ROS- 1 : negative. MSI: unknown. PD-L1 $\geq 50 \%$. The patient by that time had received two cycles of cisplatin-etoposide ther- apy. Symptomatology was significant for decreased appetite, weight loss of $4 \mathrm{~kg}$, and myelosuppression with an absolute neutrophil count of $600 \mathrm{~mm}^{3}$ (reference range: $1500-8000 \mathrm{~mm}^{3}$ ). TNM stage $\mathrm{cT}_{4} \mathrm{~N}_{2} \mathrm{M}_{\mathrm{lb}}$.

Patient was initiated on pembrolizumab and the combination of cisplatin-etoposide was discontinued after two cycles. Immunotherapy was well tolerated by the patient. After 3 cycles of immunotherapy, the CEA level was $5.3 \mathrm{ng} / \mathrm{mL}$, and the complete blood count was within reference range. The patient did not suffer from electrolyte abnormalities, and gained $3 \mathrm{~kg}$. After the 5th cycle of pembrolizumab, follow-up CT showed a reduction of $45 \%$ in tumor size. Symptomatology was relevant for iron-deficiency anemia which is being treated with iron supplementation. After the 10th cycle of pembrolizumab, the patient's CEA increased to 17.3. Scheduled chest CT showed progression at the primary site without evidence of progression at metastatic sites. PET-CT showed a large upper lobe mass consistent with the patient's known NSCLC primary with interval growth of lesion in the right thoracic inlet, but with decrease in size and activity of right hilar lymphadenopathy and left adrenal metastasis. Findings are consistent with a mixed response but large amount of persistent residual disease.

Patient therapy after 10 cycles of pembrolizumab has been switched to 3rd line therapy with ramucirumab and docetaxel. Patient's symptomatology is negligible.

\section{Discussion}

The diagnosis of HAC is a complicated process as it is difficult to differentiate from metastatic hepatocellular carcinoma (HCC), even in the absence of a visible primary tumor in the liver. The data in Table 1 shows that 21 of the listed patients had their AFP measured prior to the initiation of treatment. Although 20 patients presented with elevated serum AFP levels, our case and the case reported by Grossman et al. [5] showed normal serum AFP levels. As a result, serum AFP cannot be used as a diagnostic criterion for HAC. Furthermore, a study has shown that when the cutoff value is of $20 \mathrm{ng} / \mathrm{ml}$, serum AFP has a sensitivity of $41-65 \%$ and a specificity of $80-94 \%$ [33]. This low sensitivity indicates that serum AFP level is not reliable for the detection of HCC. In the setting of an extrahepatic tumor showing hepatic-like features and an absence of a primary tumor in the liver on diagnostic imaging, the reported specificity supports the ruling out of HCC on the basis of negative serum AFP test. There have also been reports of CEA-producing HAC in the literature, but not enough evidence suggests the use of CEA levels as a diagnostic criterion. This marker can however be used in a clinical setting to monitor disease progression. This patient presented with an elevated CEA that did not change in response to treatment with cisplatin-etoposide. This was expected due to the lack of any positive response to the chemothera- 
Table 2 Summary of the patient's clinical course

\begin{tabular}{|c|c|c|c|c|}
\hline Date & Clinical course & $\operatorname{AFP}(\mathrm{ng} / \mathrm{mL})$ & CEA (ng/mL) & Imaging \\
\hline April 19, 2018 & Prior to treatment & 1.5 & 32.0 & $\begin{array}{l}\text { Chest CT showing a } 9.3 \times 7.2 \mathrm{~cm} \text { mass located in the upper } \\
\text { lobe of the right lung (RUL) PET-CT hilar lymphadenopathy } \\
\text { and left adrenal metastasis }\end{array}$ \\
\hline June 6, 2018 & $\begin{array}{l}\text { Status post } 2 \text { cycles of cisplatin- } \\
\text { etoposide }\end{array}$ & 1.5 & 31.7 & $\mathrm{~N} / \mathrm{A}$ \\
\hline August 29, 2018 & Status post 2 cycles of pembrolizumab & $\mathrm{n} / \mathrm{a}$ & 5.7 & $\mathrm{~N} / \mathrm{A}$ \\
\hline October 10, 2018 & Status post 5 cycles of pembrolizumab & $\mathrm{n} / \mathrm{a}$ & 5.3 & Chest CT shows $45 \%$ reduction in mass \\
\hline December 2018 & Status post 9 cycles of pembrolizumab & n/a & 6.2 & $\mathrm{~N} / \mathrm{A}$ \\
\hline January 23, 2019 & Status post 10 cycles of pembrolizumab & $\mathrm{n} / \mathrm{a}$ & 17.3 & $\begin{array}{l}\text { Chest CT shows growth of primary mass in RUL } \\
\text { PET-CT shows a RUL mass measuring } 8.4 \times 9.0 \mathrm{~cm} \text { and } \\
\text { a right thoracic inlet mass measuring } 3.1 \times 3.6 \mathrm{~cm}\end{array}$ \\
\hline
\end{tabular}

peutic treatment. CEA levels had decreased and stabilized after switching to pembrolizumab and had been stable until December 2018, a period of 6 months. A serial rise in CEA (Table 2) prompted a CT scan which indicated progression at the primary site. This evidence is suggestive that CEA could be used to clinically monitor CEA-producing NSCLC.

The rarity of this type of tumors does not allow to define a standard treatment. There is no generalized consensus about the treatment of HAC, but based on previously published case reports, surgical resection and neoadjuvant chemotherapy is the treatment of choice for non-advanced HAC of the lung ([4]; Table 1). In the case we bring forward, the patient's stage at presentation did not make them eligible for surgery and they were thus started on cisplatin and etoposide. The use of this combination is reported as both a primary intervention in the setting of advanced disease or as neo-adjuvant therapy in the setting of a resectable tumor (Table 1).

The disappointing response to chemotherapy prompted the decision to change the treatment regimen to an immunotherapeutic agent. Pembrolizumab is a PD-L1 receptor antagonist that has been approved by the FDA for the treatment of NSCLC with high PDL1 expression and as first line treatment of advanced NSCLC regardless of PD-L1 expression. The PD-L1 ${ }^{+}$ immunohistochemical profile of the tumor supports the use of pembrolizumab for treatment. This is the first reported use of pembrolizumab in a case of hepatoid adenocarcinoma. We believe that this highlights the importance of immunohistochemical analysis in the management of HAC specifically, and NSCLC generally. We recommend that all patients with NSCLC be investigated for immunohistochemical markers prior to initiation of treatment, which will allow for targeted therapy. The adoption of an immunotherapeutic treatment regimen has allowed for a treatment course less burdened with symptoms, 6 months after the discontinuation of cisplatin-etoposide. The reduction in tumor activity seen in previously highly active hilar area and left adrenal gland is indicative of the efficacy of pembrolizumab in the management of PD-L1 positive NSCLC. Unfortunately, the primary mass had progressed to its approximate size at pre- sentation and the mixed response to immunotherapy has warranted an escalation to third line therapy with ramucirumab and docetaxel in accordance with FDA-approved guidelines for the management of treatment-resistant NSCLC. As previous case reports indicate, prognosis of HAC of the lung is poor [5], especially for non-resectable disease (Table 1). Patient's clinical course has spread over 10 months as of February 10, 2019. This also indicated a promising result for the use of immune-targeted therapy in the management of advanced HAC of the lung.

Patient is status post 3 cycles of ramucirumab. Tolerating therapy well and with negative symptomatology. Last CT shows a regression of the primary mass in the RUL and the mass in the right thoracic inlet. Time since diagnosis: 14 months.

Author Contribution A. El Khoury and M. El Khoury wrote the manuscript under guidance and direction from R. De Luca.

\section{Compliance with ethical guidelines}

Conflict of interest A. El Khoury, M. El Khoury and R. De Luca declare that they have no competing interests.

Ethical standards Written consent for the publication of this case has been obtained from the patient.

Open Access This article is distributed under the terms of the Creative Commons Attribution 4.0 International License (http://creativecommons.org/licenses/by/4.0/), which permits unrestricted use, distribution, and reproduction in any medium, provided you give appropriate credit to the original author(s) and the source, provide a link to the Creative Commons license, and indicate if changes were made.

\section{References}

1. Ishikura $\mathrm{H}$, et al. An AFP-producing gastric carcinoma with features of hepatic differentiation. a case report. Cancer. 1985;56(4):840-8. https://doi.org/10.1002/10970142(19850815)56:4.

2. Arnould L, et al. Hepatoid Adenocarcinoma of the lung: report of acase of an unusual $\alpha$-Fetoprotein-producinglung tumor. Am J Surg Pathol. 1997;21(9):1113-8. https://doi. org/10.1097/00000478-199709000-00018. 
3. Su JS, et al. Clinicopathological characteristics in the differential diagnosis of Hepatoid Adenocarcinoma: a literature review. World J Gastroenterol. 2013;19(3):321-7. https:// doi.org/10.3748/wjg.v19.i3.321.

4. Simmet V, et al. Chemotherapy of metastatic Hepatoid Adenocarcinoma: literature review and two case reports with Cisplatin Etoposide. Oncol Lett. 2018;15(1):48-54 https://doi.org/10.3892/ol.2017.7263.

5. Grossman K, et al. Hepatoid Adenocarcinoma of the lung: review of a rare form of lung cancer. Respir Med. 2016;119:175-9. https://doi.org/10.1016/j.rmed.2016.09. 003.

6. Shao Y, et al. Hepatoid Adenocarcinoma of the lung: a case report. Int JClin Exp Pathol. 2016;9(3):4067-4072.

7. Yasunami R, et al. Primary lung cancer producing AlphaFetoprotein: a case report. Cancer. 1981;47(5):926-9. https://doi.org/10.1002/1097-0142(19810301)47:5.

8. Yokoyama K, et al. An autopsied case of Alpha-Fetoprotein (AFP) producinglarge cell carcinoma of the lung. Japanese J Thorac Surg. 1981;34(8):609-12. Author's Translation.

9. Miyake M, et al. A case report of two patients with primary lung cancer secreting AFP. J Japanese Assoc Thorac Surg. 1986;34(6):914-9.

10. Miyake M, et al. Alpha-fetoprotein and human Chorionic Gonadotropin-producing lung cancer. Cancer. 1987;59(2):227-32. https://doi.org/10.1002/10970142(19870115)59:2.

11. Okunaka T, etal. Primarylung cancer producing $\alpha$-Fetoprotein. Ann Thorac Surg. 1992;53(1):151-2. https://doi.org/ 10.1016/0003-4975(92)90778-3.

12. Nasu M, et al. Hepatoid carcinoma of the lung with production of Alpha-Fetoprotein and abnormal Prothrombin: an autopsy case report. Mod Pathol. 1997;10(10):1054-8.

13. Carlinfante G, et al. Hepatoid carcinoma of the lung: a case report with Immunohistochemical, ultrastructural and in-situ hybridization findings. Histopathology. 2000;37(1):85-95. https://doi.org/10.1046/j.1365-2559. 2000.00955-5.x.

14. Genova S. Hepatoid Adenocarcinoma of the lung: a case report. Internet J Pathol. 2002;2:1-5.

15. Hayashi Y, et al. Hepatoid adenocarcinoma in the lung. Cancer TreatRes. 2002;38:211-4.

16. Hiroshima K, et al. Alpha-Fetoprotein-producing lung carcinoma: report of three cases. Pathol Int. 2002;52(1):46-53. https://doi.org/10.1046/j.1440-1827.2002.01311.x.

17. Iino K, et al. A Resected case of Alpha-Fetoprotein-producing Hepatoid Adenocarcinoma of the lung. Japanese J Lung Cancer. 2003;43:29-34.

18. OshiroY, etal. AResected case of Metachronous liver metastasis from lung cancer producing Alpha-Fetoprotein (AFP) and protein induced by vitamin K absence or antagonist II (PIVKA-II). Hepatogastroenterology. 2004;51(58):1144-7.

19. Ivan $M$, et al. Hepatoid Adenocarcinoma of the lung. Chest. 2007;132(4):690.

20. Kishimoto T, et al. A case of $\alpha$-Fetoprotein-producing pulmonary carcinoma with restricted expression of Hepatocyte nuclear factor- $4 \alpha$ in Hepatoid foci: a case report with studies of previous cases. Hum Pathol. 2008;39(7):1115-20. https://doi.org/10.1016/j.humpath.2007.12.013.

21. Kim L, et al. Hepatoid Adenocarcinoma arising in the lung: a case report. BasicAppl Pathol. 2009;2:47.
22. Valentino F, et al. Synchronous presentation of Hepatoid Alpha-Fetoprotein-producing lung cancer and Colorectal Adenocarcinoma. Tumori. 2012;98(5):e130-e4. https:// doi.org/10.1038/s41598-018-24734-z.

23. Lin S-F, et al. Primary pulmonary Hepatoid carcinoma: report of a case and review of the literature. Kao Hsiung I Hsueh Ko Hsueh Tsa Chih. 2013;29(9):512-6. https://doi. org/10.1016/j.kjms.2013.01.007.

24. Haninger DM, et al. Hepatoid Adenocarcinoma of the lung: report of five cases and review of the literature. Mod Pathol. 2014;27(4):535-42. https://doi.org/10.1038/modpathol. 2013.170 .

25. Shaib W, et al. Hepatoid Adenocarcinoma of thelung: a case report and review of the literature. J Gastrointest Cancer. 2014;45(1):99-102. https://doi.org/10.1007/s12029-0139558-7.

26. Che Q-Y, et al. Hepatoid Adenocarcinoma of the lung: presenting Mediastinal metastasis without transfer to the liver. Oncol Lett. 2014;8(1):105-10. https://doi.org/10. 3892/ol.2014.2064.

27. Gavrancic T, Park Y-H. A novel approach using Sorafenib in Alpha Fetoprotein-producing Hepatoid Adenocarcinoma of the lung. J Natl Compr Cancer Netw. 2015;13(4):387-91. https://doi.org/10.6004/JNCCN.2015.0054. quiz391.

28. Qian GQ, et al. Hepatoid Adenocarcinoma of the lung. QJM. 2016;109(9):619-20.https://doi.org/10.1093/qjmed/ hcwl07.

29. Motooka Y, et al. Pulmonary Hepatoid Adenocarcinoma: report of a Case. Surg Case Rep. 2016;2(1):1. https://doi. org/10.1186/s40792-016-0129-6.

30. Sun JN, et al. Hepatoid Adenocarcinoma of thelung without production of $\alpha$-Fetoprotein: a case report and review of the literature. Oncol Lett. 2016;12(1):189-94. https://doi.org/ $10.3892 /$ ol.2016.4559.

31. Valle L, et al. Hepatoid Adenocarcinoma of the lung metastasizing to the tonsil. Mol Clin Oncol. 2017;6(5):705-7. https://doi.org/10.3892/mco.2017.1215.

32. Basse V, et al. A mismatch repair-deficient Hepatoid Adenocarcinoma of the lung responding to anti-PD-L1 Durvalumab therapy despite no PD-L1 expression. JThorac Oncol. 2018;13(7):e120-e2. https://doi.org/10.1016/j.jtho. 2018.03.004.

33. Debruyne EN, Delanghe JR. Diagnosing and monitoring Hepatocellular carcinoma with Alpha-Fetoprotein: new aspects and applications. Clin Chimica Acta. 2008;395(1-2):19-26. https://doi.org/10.1016/J.CCA.2008. 05.010 .

Publisher's Note Springer Nature remains neutral with regard to jurisdictional claims in published maps and institutional affiliations.

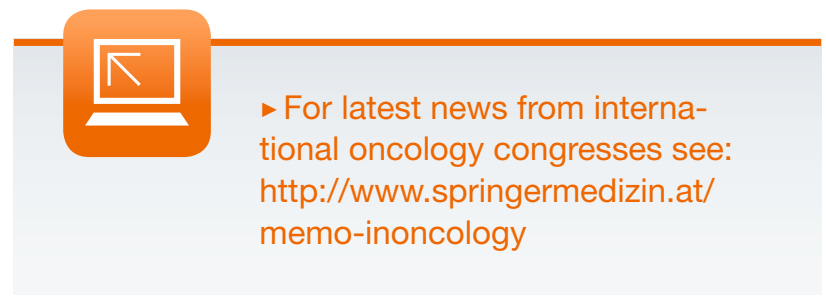

